\title{
PERTUMBUHAN DAN HASIL PENANANAM KEDELAI \\ (Glycine max L. Merrill) VARIETAS GROBOGAN DAN ANJASMORO AKIBAT KEKERINGAN DI SIDOHARJO, KABUPATEN WONOGIRI
}

\author{
Sumarmi dan Kharis Triyono \\ Fakultas Pertanian Universitas Slamet Riyadi Surakarta \\ felt.sumarmi@gmail.com
}

\begin{abstract}
ABSTRAK
Salah satu penghasil kedelai di Kabupaten Wonogiri adalah Kecamatan Sidoharjo. Penelitian ini bertujuan untuk membuat analisis pertumbuhan dan hasil penanaman kedelai kultivar Grobogan dan Anjasmoro akibat kekeringan di desa Mojoreno, Kecamatan Sidoharjo. Penanaman dilakukan di lahan sawah luas 300 meter persegi, sesudah selesai bertanam padi. Selama kedelai tumbuh, bulan Juni sampai panen September 2018 tidak pernah terjadi hujan dan tidak ada hujan kiriman. Hasil pertumbuhan kedelai berdasarkan tinggi tanaman yang diukur mulai umur 3 minggu sampai 9 minggu menunjukkan rerata 34,83 cm untuk kultivar Grobogan dan 32,48 cm untuk kultivar Anjasmoro. Pada kondisi normal kedelai bisa tumbuh hingga 50-60 cm. Jumlah anak daun kedelai hanya 18 lembar pada kultivar Grobogan dan 17 lembar pada kultivar Anjasmoro. Bunga kedelai tetap terbentuk, meskipun tumbuh dalam kondisi tanah kering dan jumlahnya mencapai 26 pada kultivar Grobogan dan 35 pada kultivar Anjasmoro. Akibat kekeringan menyebabkan banyak bunga gugur dan gagal menjadi buah polong. Penyusutan hasil panen dihitung dari berat awal benih yang ditanam: Grobogan susut hingga 52\%, sedangkan Anjasmoro turun hingga 39\%. Kedelai kultivar Anjasmoro lebih tahan kekeringan dibandingkan kultivar Grobogan.
\end{abstract}

Kata kunci: kedelai, kekeringan, kultivar Grobogan, Anjasmoro

GROWTH AND RESULTS OF SOYBEAN (Glycine max L. Merrill) GROBOGAN
AND ANJASMORO VARIETY EFFECT OF DROUGHT IN MOJORENO
VILLAGE, DISTRICT OF SIDOHARJO, WONOGIRI REGENCY

Sumarmi dan Kharis Triyono

Fakultas Pertanian Universitas Slamet Riyadi Surakarta

felt.sumarmi@gmail.com

\section{ABSTRACT}

One of the soybean producers in Wonogiri Regency is Sidoharjo District. This study aims to analyze the growth and yield of planting Grobogan and Anjasmoro cultivar soybean due to drought in Mojoreno village, Sidoharjo District. Planting was carried out in 300 square meters of rice fields, after finishing planting rice. As long as soybeans are growing, in June until the September 2018 harvest, there will never be rain and there will be no rain of shipment. The results of soybean growth based on plant height measured from the age of 3 weeks to 9 weeks showed an 
average of $34.83 \mathrm{~cm}$ for Grobogan cultivars and $32.48 \mathrm{~cm}$ for Anjasmoro cultivars. Under normal conditions soybeans can grow up to 50-60 cm. The number of soybean leaves was only 18 sheets in Grobogan cultivar and 17 sheets in Anjasmoro cultivar. Soybean flowers are still formed, although they grow in dry soil conditions and the number reaches 26 in Grobogan cultivars and 35 in Anjasmoro cultivars. As a result of drought, many flowers fall and fail to become pods. Depreciation of yields was calculated from the initial weight of the seeds planted: Grobogan down to 52\%, while Anjasmoro reduced by 39\%. The drought conditions in 2018 are considered to be bad for soybean farming in Mojoreno village, Sidoharjo District, Wonogiri Regency.

Keywords: soybeans, drought, Grobogan cultivars, Anjasmoro

\section{PENDAHULUAN}

Sampai sekarang Indonesia belum bisa swasembada kedelai. Import kedelai pada tahun 2015 mencapai 1.668 .800 ton menunjukkan bahwa masih jauh dari kemandirian pangan. Diperkirakan pada tahun 2020 produksi kedelai nasional mencapai 1.475.965 ton sedangkan konsumsi kedelai nasional mencapai 3.012.377 ton, sehingga terjadi defisit rata-rata sebesar 1,6 juta ton per tahun (Aldillah, 2015).

Berbagai penurunan hasil panen kedelai yaitu menurunnya produksi disebabkan karena faktor internal dan eksternal. Faktor eksternal termasuk faktor lingkungan seperti kesuburan tanah yang berkurang, ketergantungan pada pupuk yang sangat tinggi dan curah hujan atau kekeringan yang tidak normal. Faktor internal yaitu faktor dari dalam kedelai itu sendiri misalnya faktor benih dan sering menjadi alasan mengapa produksi kedelai turun.

Kedelai tumbuh baik di tempat berhawa panas, di tempat terbuka dan curah hujan 100-400 $\mathrm{mm}^{3}$ per bulan. Kedelai dapat ditanam di daerah yang terletak antara 400 sampai $600 \mathrm{~m}$ dpl. Kedelai tumbuh baik jika ditanam di daerah beriklim kering. Di Indonesia, kedelai ditanam pada musim mareng (musim kemarau), setelah panen padi, karena hujan masih turun beberapa kali. Temperatur berkisar antara $28-38^{0} \mathrm{C}$ diperlukan untuk awal terbentuknya bunga hingga berkembang menjadi polong kedelai (Thuzar, et al. 2010).

Kekurangan air pada musim kemarau menyebabakan terjadinya cekaman kekeringan dan berakibat rendahnya hasil panen kedelai. Kekeringan pada kedelai 
menyebabkan efek fisiologis berupa tekanan pertumbuhan dan produksi (Saputra, et al. 2015). Kekeringan mempengaruhi hasil, kandungan hara yang rendah dan $\mathrm{pH}$ tanah yang tidak optimum. Cekaman kekeringan pada stadia vegetatif dapat menurunkan tinggi tanaman dan luas daun (Purwanto dan Agustono, 2010). Penelitian ini bertujuan untuk membuat analisis hasil petumbuhan kedelai yang ditanam dalam kondisi kekeringan tanpa pengairan sejak bulan Juni hingga September 2018. pada dua kultivar grobogan dan Anjasmoro di desa Mojoreno, Kecamatan Sidoharjo, kabupaten Wonogiri.

\section{BAHAN DAN METODE}

Bahan: benih kultivar tanaman kedelai yaitu Anjasmoro yang diperoleh dari Balai Penelitian Tanaman Kacang-Kacangan dan Umbi-umbian, Jl. Raya Kendalpayak, km 8 Malang. Kedelai kultivar Grobogan didapat dari Pusat penjualan benih kedelai Grobogan yaitu UD Sujinah di kota Grobogan, Propinsi Jawa Tengah.

Alat: perangkat bercocok tanam kedelai: cangkul, cetok, ember, tongkat; karung, bakul dan pengayak hasil panen; oven, timbangan digital, jangka sorong, penggaris, alat tulis, kertas milimeterblok, perangkat analisis fisik, kimia dan mikrobiologi tanah.

\section{METODE}

\section{Penanaman}

Dua kultivar kedelai ditanam pada tanggal 17 Juni 2018 ditanam di sawah desa Mojoreno dengan cara benih kedelai dibenamkan/ditugal ke tanah sedalam $2 \mathrm{~cm}$, setiap lobang diberi 2 biji kedelai. Sawah yang digunakan untuk menanam kedelai merupakan sawah sesudah selesai bertanam padi, sesuai dengan kebiasaan para petani desa setempat yang telah dilakukan selama puluhan tahun (lebih dari 40 tahun). Luas lahan yang digunakan masing-masing 300 meter persegi untuk kultivar Anjasmoro dan Grobogan. Jarak tanam yang digunakan $20 \times 20 \mathrm{~cm}$. 


\section{Perawatan Tanaman}

Perawatan tanaman kedelai menggunakan kebiasaan petani Mojoreno yaitu bergiliran mendapatkan air irigasi seminggu sekali yang selalu jatuh pada hari Minggu. Tiap hari Minggu pada jam 03.30 petani (Samidi, 80 tahun) yang merawat kedelai datang ke sawah untuk menunggu kalau ada kiriman air atau air mengalir ke parit, dengan harapan bisa untuk menyirami tanaman. Khusus tahun 2018 ini giliran untuk mendapatkan air sama sekali tidak ada karena sumber mata air kering sejak awal bulan Juni. Pertumbuhan tanaman kedelai hanya mengandalkan sisa cadangan air tanah sebelumnya, ditambah dengan tetesan air pagi hari yaitu embun. Perawatan lain seperti mencabuti rumput dilakukan seperlunya, dua minggu sekali selama 3 kali.

\section{Panen}

Panen dilakukan pada tanggal 3 September 2018, setelah tanaman siap dipanen yaitu semua daun sudah kuning kecoklatan dan batang mulai mengering. Umur tanaman pada waktu panen 78 hari. Cara panen seluruh tanaman dipotong dengan sabit, seluruh tanaman dimasukkan ke dalam karung, dibedakan atau dihimpun menjadi 2 menurut kultivar. Semua hasil panen dijemur atau dikeringkan selama 6 hari sehingga semua kulit buah polong mudah terbuka. Biji kedelai hasil panen keluar atau dibantu dikeluarkan dengan cara seluruh tanaman diinjak-injak dengan kaki, kemudian disisihkan antara kulit buah, batang kering beserta daunnya. Semua biji kedelai didapat dari hasil memilih dan sortasi dengan alat tradisional “tampah” berbentuk bundar dari anyaman bambu.

\section{Pengumpulan Data}

A. Data pertumbuhan tanaman: tinggi tanaman, jumlah daun dan jumlah bunga dan data hasil penanaman kedelai: jumlah polong yang terbentuk, berat 100 biji dan total berat hasil panen.

B. Data lokasi gambaran wilayah kecamatan Sidoharjo 


\section{HASIL DAN DISKUSI}

\section{Tinggi Tanaman Kedelai}

Pertumbuhan tanaman kedelai diukur dari pertumbuhan tinggi tanaman. Tinggi tanaman diukur setiap 3 minggu, dimulai pada saat tanaman umur 3 minggu (Tabel 1). Kedelai kultivar Anjasmoro umur 3 minggu sedikit lebih tinggi dibandingkan kultivar Grobogan. Hal itu sesuai dengan deskripsi dua kultivar kedelai tersebut. Sebenarnya tinggi tanaman kedelai umur 3 minggu lebih dari 16,0 cm apabila ditanam dengan kadar air tanah yang cukup atau kelengasan tanah sekitar 30\%. Rerata tinggi tanaman kedelai umur 6 minggu 26,2 cm untuk kultivar Grobogan dan 35,1 cm untuk kultivar Anjasmoro.

Tabel 1. Pertumbuhan tinggi tanaman kedelai kultivar Grobogan dan Anjasmoro

\begin{tabular}{ccc}
\hline & \multicolumn{2}{c}{ Tinggi tanaman (cm) kultivar } \\
\hline Umur (minggu) & Grobogan & Anjasmoro \\
\hline 3 & $14,6 \pm 0,1$ & $16,0 \pm 0,1$ \\
\hline 6 & $26,2 \pm 0,3$ & $35,1 \pm 0,1$ \\
\hline 9 & $34,83 \pm 0,4$ & $32,48 \pm 0,2$ \\
\hline 12 & $34,90 \pm 0,4$ & $32,78 \pm 0,2$ \\
\hline
\end{tabular}

Pada umur 9 minggu tanaman kedelai tumbuh, bertambah panjang menjadi 34,83 cm pada kultivar Grobogan dan 32,48 pada kultivar Anjasmoro. Tinggi tanaman kedelai umur 9 minggu yang tumbuh normal dengan pemeliharaan biasa atau tanpa perlakuan khusus, paling tidak mencapai $50 \mathrm{~cm}$ untuk kultivar Grobogan, sedangkan kultiva Anjasmoro dapat mencapai 60 cm.

Tanaman kedelai umur 9 minggu sudah bertambah tinggi karena organ generatif mulai tumbuh yaitu calon kuncup bunga. Pertumbuhan cabang masih bisa terjadi. Dalam penelitian ini pertumbuhan tinggi tanaman tidak maksimal karena kekurangan air sejak awal tumbuh hingga panen.

2. Jumlah Anak Daun

Daun merupakan bagian penting bagi semua tanaman. Daun kedelai disebut trifoliate karena terdiri dari tiga anak daun. Organ vegetatif ini berperan 
penting sejak awal pertumbuhan terutama karena fungsi utama daun sebagai tempat fotosintesis atau asimilasi. Dalam proses fotosintesis, daun menghasilkan glukosa dan Oksigen yang akan didistribusi ke seluruh tubuh sehingga tanaman akan tumbuh terus dan bertambah besar atau makin tinggi. Proses fotosintesis adalah proses nutritif yang membutuhkan dua bahan pokok yaitu air dan karbon dioksida $\left(\mathrm{CO}_{2}\right)$. Karbon-dioksida tersedia melimpah di udara, sedangkan air diambil oleh akar dari tanah. Masalah sangat terbatasnya air tanah menjadi penyebab tidak normalnya proses fotosintesis, menjadi tidak aktif atau lambat. Jumlah anak daun kedelai ada 18 lembar pada kultivar Grobogan dan 17 lembar pada kultivar Anjasmoro.

3. Luas Daun

Luas daun diukur pada saat tanaman umur 9 minggu. Luas daun yang dimaksud sama dengan anak daun. Daun diambil 10 lembar secara acak untuk kelompok daun kecil (sempit) dan 10 lembar daun kelompok besar (luas). Pengukuran luas daun menggunakan metode kertas milimeter blok. Tabel 2 menunjukkan bahwa daun kedelai kultivar Anjasmoro lebih luas daripada kultivar Grobogan.

Tabel 2. Luas daun kedelai

\begin{tabular}{cccc}
\hline Kultivar & \multicolumn{2}{c}{ Luas daun $\left(\mathrm{cm}^{2}\right)$} & Rerata $\left(\mathrm{cm}^{2}\right)$ \\
\hline \multirow{2}{*}{ Grobogan } & kecil & besar & \\
\cline { 2 - 3 } & $4,8 \pm 0,2$ & $10,1 \pm 0,2$ & $7,5 \pm 0,2$ \\
\hline Anjasmoro & $9,9 \pm 0,2$ & $12,1 \pm 0,1$ & $11,0 \pm 0,1$ \\
\hline
\end{tabular}

Luas daun kedelai dalam kondisi tumbuh baik dapat mencapai lebih dari $30 \mathrm{~cm}^{2}$. Luas daun hasil penanaman kedelai dalam kondisi kekeringan hanya sepertiga dari luas daun tanaman kedelai normal. Cekaman kekeringan pada tanaman kedelai telah menurunkan luas daun kedelai 60-70\%. Cekaman kekeringan dapat mengurangi laju pelebaran daun, bahkan sebagian stomata daun dapat tertutup untuk mengurangi penguapan. Kondisi tersebut akan menurunkan karbon dioksida yang masuk lewat mulut daun (Purwanto dan Agustono, 2010). 


\section{Jumlah Bunga}

Tanaman kedelai pada umur 5 sampai 6 minggu sudah mulai berbunga, meskipun tanaman tidak bisa tumbuh tinggi dan jumlah daun tidak banyak. Sekilas dilihat dari jauh tanaman kedelai yang ditanam pada musim kemarau dengan kondisi kekeringan seperti tidak ada harapan akan tumbuh bunga. Cukup mengherankan karena bunga tetap muncul dan jumlahnya mencapai 26 pada kultivar Grobogan dan 35 pada kultivar Anjasmoro. Gambar 1 menunjukkan kondisi tanah kering dengan beberapa tanaman kedelai yang masih dapat tumbuh. Gambar 2. menunjukkan salah satu tanaman kedelai kultivar Grobogan umur 6 minggu. Diperkirakan faktor benih merupakan faktor penting untuk menjamin keberhasilan pertumbuhan, selain faktor kondisi lingkungan.

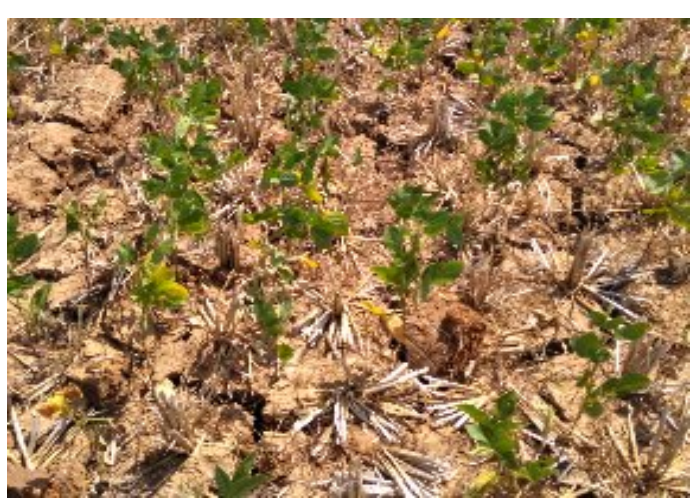

Gambar 1. Tanaman kedelai di lahan kering

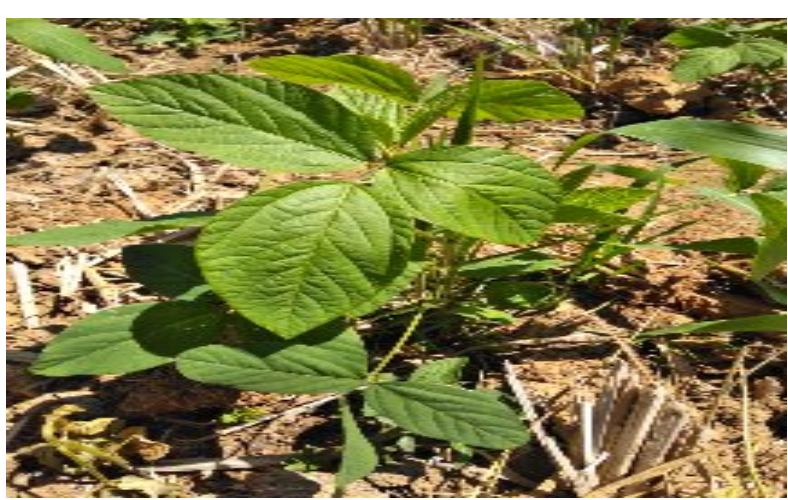

Gambar 2. Kedelai kultivar Grobogan umur 6 minggu

Dilihat dari munculnya bunga, ke dua kultivar sudah sesuai dengan deskripsi, akan tetapi jumlah bunganya sangat sedikit. Beda jauh dengan kondisi normal. Jumlah bunga tergantung dari jumlah cabang karena munculnya bunga kedelai banyak di ketiak cabang. Jumlah cabang tergantung dari kondisi umum pertumbuhan tanaman. Tanaman yang dapat tumbuh tinggi dan sehat akan membentuk 7-9 cabang, dalam hal ini karena kekeringan tanaman tertinggi hanya 40,5 cm dan jumlah rata-rata hanya tiga cabang. Hal ini berpengaruh pada jumlah bunga yang terbentuk. Selain jumlah bunga yang terbentuk ada hal lain penting yaitu tidak semua bunga membentuk polong bernas artinya akibat kekeringan banyak bunga mandul atau tidak terjadi pembuahan yang sempurna. 
Akibat kekeringan menyebabkan banyak bunga gugur dan gagal menjadi buah polong pada kedelai.

5. Jumlah Polong Yang Terbentuk

Sesudah tumbuh bunga, akan terbentuk calon buah polong (bahasa Jawa: kepek). Tidak semua bunga berlanjut tumbuh menjadi buah polong. Dapat dikatakan bahwa tidak ada korelasi antara jumlah bunga dengan jumlah buah polong. Jumlah buah polong yang terbentuk pada kedelai kultivar Gobogan rata-rata per tanaman hanya 8,4, sedangkan pada kultivar Anjasmoro hanya ada 7,2 buah polong isi per tanaman. Hal ini menunjukkan bahwa buah polong tidak terus tumbuh atau berisi biji karena sebagian gugur pada waktu masih kepek akibat kekeringan atau kemarau panjang.

6. Berat 100 biji kedelai

Berdasarkan bijinya kedelai dibedakan menjadi kelompok berbiji besar dan berbiji kecil. Kedelai berbiji kecil apabila berat 100 biji kurang dari atau sama dengan 15 gram. Rata-rata hasil penimbangan 100 biji kedelai hasil panen di lahan kering desa Mojoreno, Kecamatan Sidoharjo, kabupaten Wonogiri menunjukkan bahwa berat kultivar Grobogan adalah 14,40 gram, sedangkan untuk kultivar Anjasmoro 17,55 gram. Bobot 100 biji kedelai kultivar Anjasmoro lebih besar dari deskripsi kultivar yang sama dari Balai Penelitian Kacang-kacangan dan Umbi (Balitkabi).

Kedelai varietas lokal Grobogan biasanya menjadi pilihan petani Jawa Tengah, khususnya petani Kabupaten Grobogan. Varietas lokal ini mempunyai keunggulan umurnya lebih pendek, polongnya besar, dan tingkat kematangan polong dan daun bersamaan, jadi pada saat dipanen daun kedelai sudah rontok. Keunggulan inilah yang menarik minat peneliti untuk memurnikan varietas ini. Pada tahun 2008, hasil pemurnian populasi lokal Malabar Grobogan ini dilepas dengan nama varietas Grobogan. Varietas kedelai dengan potensi hasil 3,40 t/ha ini telah diuji coba dengan rata-rata hasil 2,77 t/ha. Penelitian ini menunjukkan bahwa kedelai kultivar Anjasmoro lebih tahan kering dan menghasilkan bobot 100 biji lebih besar dibandingkan kedelai kultivar Grobogan. 
Peningkatan produksi kedelai di lahan kering dapat ditempuh dengan cara menanam kultivar yang adaptif dengan kondisi lingkungan setempat atau kultivar yang toleran terhadap lahan kering. Besarnya kerugian yang ditimbulkan akibat kekeringan ditentukan oleh kultivar, lamanya cekaman dan stadia tumbuh (Saputra, et al. 2015).

Menurut pengalaman petani desa Mojoreno, Sidoharjo, dalam kondisi yang baik setiap $1 \mathrm{~kg}$ benih kedelai akan menghasilkan $30 \mathrm{~kg}$ kedelai hasil panen. Berdasarkan deskripsi tentang kultivar Grobogan akan tumbuh baik jika ditanam di daerah dengan irigasi yang baik, sehingga wajar apabila hasil pertumbuhan tanaman kurang baik karena meskipun saluran irigasi sudah ada dan sudah baik akan tetapi tidak ada air yang mengalir.

Kondisi kekeringan pada tahun 2018 ini termasuk buruk karena pada tahun 2017 pada bulan April masih ada hujan dengan curah tinggi, dan yang terjadi pada tahun 2016 awal bulan Juni juga masih ada hujan. Pada tahun 2018 ini bulan April sama sekali tidak ada hujan, dan sampai dengan tanggal 29 Oktober 2018 masih banyak daerah di Jawa Tengah yang belum terjadi hujan sama sekali. Selain tidak ada hujan, hujan kiriman sama sekali juga tidak ada. Dalam keadaan seperti ini banyak petani membiarkan lahan tanpa tanaman sama sekali (“bera”) dengan pertimbangan apabila ditanami akhirnya tetap saja gagal panen.

7. Berat biji kedelai hasil panen

Pada waktu awal tanam, digunakan 2.000 benih kultivar Grobogan, berat biji hasil panen 950 gram. Berat biji kedelai hasil panen pada kultivar Anjasmoro : 610 gram, dari 1.000 gram benih yang ditanam. Berat biji hasil panen dihitung pada kultivar Grobogan adalah 47,5\% dari berat total biji yang ditanam sebanyak $2 \mathrm{~kg}$, sedangkan Anjasmoro berkurang hingga 39\% atau hasil panen hanya 61\% dari 1 kg biji yang ditanam. Kekeringan menyebabkan proses pengisian biji kedelai menjadi tidak sempurna atau abnormal. Kondisi ini berlanjut pada proses pemasakan biji, sehingga tampak hasil panen kedelai biji tidak utuh, mudah retak, remah tidak padat, sebagian kulit biji berwarna kehijauan tidak kuning, atau berbintik hitam. 
Menurut berita Solopos, 29 Agustus 2017 petani Kismantoro, Wonogiri menanam kedelai varietas Wilis seluas 45 hektar dan 5 hektar ditanami kedelai Wilis tumpangsari dengan jagung. Hasil panen rata-rata tiap hektar mencapai 1,6 ton per hektar, dengan harga jual per kilogram Rp 7.200,--

Penelitian yang dilakukan di Mojoreno, Sidoharjo, Wonogiri ditanam pada 17 Juni dan dipanen pada tanggal 3 September 2018, artinya umur tanaman kedelai varietas Grobogan dan Anjasmoro hanya 78 hari. Umur tanaman yang menjadi lebih “cepat” panen karena seluruh tanaman sudah menguning dan mulai mengering karena pada tahun 2018 terjadi kekeringan tanpa hujan dan kemarau panjang (sampai tanggal 31 Oktober belum ada hujan). Pedoman petani jika sudah ada hujan selama 3 hari berturut-turut maka baru disebut memasuki musim hujan.

C. Data Lokasi Kecamatan Sidoharjo

Luas Wilayah: 5.719,7045 ha. Wilayah administrasi : 2 Kel., 10 Desa dan 101 RW, 349 RT. Jarak : 20 km di sebelah timur Kota Wonogiri. Ketinggian : 348 m dari permukaan air laut. Batas wilayah Sebelah utara : Kec. Girimarto, Sebelah timur : Kecamatan Jatisrono dan Jatiroto, Sebelah selatan : Kecamatan Tirtomoyo, Sebelah barat : Kecamatan Ngadirojo. Hasil pertanian Kecamatan Sidoharjo : padi, padi gogo, jagung, ubi kayu, kacang tanah dan kedelai. Hasil tanaman buah-buah yang ada antara lain rambutan, pepaya dan melinjo.

\section{KESIMPULAN}

Kedelai kultivar Grobogan dan Anjasmoro yang ditanam pada bulan Juni 2018 di desa Mojoreno, kecamatan Sidoharjo, Kabupaten Wonogiri dapat tumbuh, tinggi tanaman $33 \mathrm{~cm}$, menghasilkan bunga sebanyak 26 pada kultivar Grobogan dan 35 pada kultivar Anjasmoro, akan tetapi hanya 8 yang membentuk buah polong berisi biji kedelai. Kedelai umur 78 hari dipanen karena seluruh tanaman sudah mengering dan polong sudah membuka. Berat hasil panen hanya 47,5 \% dari kondisi panen normal untuk kultivar Grobogan, sedangkan Anjasmoro susut hingga 39\%, akibat kekeringan. 


\section{UCAPAN TERIMA KASIH}

Penelitian ini didukung dana Program kerja LPPM Universitas Slamet Riyadi, terima kasih kepada semua pejabat yang terkait dengan hal tersebut. Terima kasih kepada para petani dusun Wates, desa Mojoreno, Kecamatan Sidoharjo, Kabupaten Wonogiri khususnya keluarga Bapak Samidi. Terima kasih juga kepada Gery, Sapto, Anggita dan Faiq, mahasiswa Fakultas Pertanian UNISRI yang telah membantu panen kedelai.

\section{DAFTAR PUSTAKA}

Aldillah, R. 2015. Proyeksi produksi dan konsumsi kedelai Indonesia. Jurnal Ekonomi Kuantitatif Terapan 8(1): 9-23.

Balitkabi, Badan Penelitian Kacang-kacangan dan Umbi-umbian Indonesia, 2014, http://balitkabi.litbang.pertanian.go.id

Griffiths A.J.F., Miller J.H. and Suzuki D.T. 2000. An introduction to genetic analysis. 7th edition. W. H. Freeman and Company. New York. https: // www.ncbi.nlm.nih.gov/books/NBK22098. Diakses 10 November 2016

Jumakir dan Endrizal. 2012. Produktivitas Kedelai Varietas Anjasmoro Melalui Pendekatann Ptt Pada Lahan Sub Optimal Di Provinsi Jambi. http:// fitoremediasi.blogspot.com/2012/02/

produktivitas-kedelai-varietas-anjasmoro-melalui-pendekatann-ptt-pada-l ahan-sub-optimal-di-provinsi-jambi.html. Diakses pada hari Senin, 30 Januari 2017.

Purwanto dan T.Agustono, 2010. Kajian Fisiologi Tanaman Kedelai pada Berbagai Kepadatan Gulma Teki Dalam Kondisi Cekaman Kekeringan. J. Agroland 17 (2): 85-90

Puteh, A.B., Thuzar, M., Mohd Monjurul Alam Mondal, M.M.A., Abdullah, N.A.P. B. and Halim, M.R.A. 2013. Soybean [Glycine max (L.) Merrill] seed yield response to high temperature stress during reproductive growth stages. AJCS 7(10):1472-1479.

Saputra, D., Timotiwu, P.B. dan Ermawati. 2015. Pengaruh Cekaman Kekeringan Terhadap pertumbuhan dan Produksi Benih Lima Varietas Kedelai. J.Agrotek Tropika.3 (1): 7-13. 
Thuzar, M, Puteh, A.B., Abdullah, N. A. P., Mohd. Lassim, M. B. and Jusoff, K. 2010. The effects of temperature stress on the quality and yield of soya bean [(Glycine max L.) Merrill.]. Journal of Agricultural Science 2 (1): 172-179.

Zakaria, A.K. 2010. Program pengembangan agribisnis kedelai dalam peningkatan produksi dan pendapatan petani, Jurnal Litbang Pertanian, 29(4):147-153. 